\title{
The new city regulators: Platform and public values in smart and sharing cities
}

Citation for published version (APA):

Ranchordás, S., \& Goanta, C. (2020). The new city regulators: Platform and public values in smart and sharing cities. Computer Law and Security Review, 36, 1-15. [105375]. https://doi.org/10.1016/j.clsr.2019.105375

Document status and date:

Published: 01/04/2020

DOI:

10.1016/j.clsr.2019.105375

Document Version:

Publisher's PDF, also known as Version of record

Document license:

Taverne

Please check the document version of this publication:

- A submitted manuscript is the version of the article upon submission and before peer-review. There can be important differences between the submitted version and the official published version of record.

People interested in the research are advised to contact the author for the final version of the publication, or visit the DOI to the publisher's website.

- The final author version and the galley proof are versions of the publication after peer review.

- The final published version features the final layout of the paper including the volume, issue and page numbers.

Link to publication

\footnotetext{
General rights rights.

- You may freely distribute the URL identifying the publication in the public portal. please follow below link for the End User Agreement:

www.umlib.nl/taverne-license

Take down policy

If you believe that this document breaches copyright please contact us at:

repository@maastrichtuniversity.nl

providing details and we will investigate your claim.
}

Copyright and moral rights for the publications made accessible in the public portal are retained by the authors and/or other copyright owners and it is a condition of accessing publications that users recognise and abide by the legal requirements associated with these

- Users may download and print one copy of any publication from the public portal for the purpose of private study or research.

- You may not further distribute the material or use it for any profit-making activity or commercial gain

If the publication is distributed under the terms of Article $25 \mathrm{fa}$ of the Dutch Copyright Act, indicated by the "Taverne" license above, 


\title{
The New City Regulators: Platform and Public Values in Smart and Sharing Cities
}

\author{
Sofia Ranchordás, $P h D^{a, 1,1, *}$, Catalina Goanta, $\mathrm{PhD}^{b}$ \\ ${ }^{a}$ Faculty of Law, University of Groningen, the Netherlands \\ ${ }^{\mathrm{b}}$ Maastricht University, Maastricht Private Law, the Netherlands
}

\section{A R T I C L E I N F O}

Keywords:

Digital platforms

Smart cities

Internet-of-things

Public values

Privacy

Urban law

\begin{abstract}
A B S T R A C T
Cities are increasingly influenced by novel and cosmopolitan values advanced by transnational technology providers and digital platforms. These values which are often visible in the advancement of the sharing economy and smart cities, may differ from the traditional public values protected by national and local laws and policies. This article contrasts the public values created by digital platforms in cities with the democratic and social national values that the platform society is leaving behind. It innovates by showing how co-regulation can balance public values with platform values. In this article, we argue that despite the value-creation benefits produced by the digital platforms under analysis, public authorities should be aware of the risks of technocratic discourses and potential conflicts between platform and local values. In this context, we suggest a normative framework which enhances the need for a new kind of knowledge-service creation in the form of local public-interest technology. Moreover, our framework proposes a negotiated contractual system that seeks to balance platform values with public values in an attempt to address the digital enforcement problem driven by the functional sovereignty role of platforms.
\end{abstract}

() 2019 Sofia Ranchordás and Catalina Goanta. Published by Elsevier Ltd. All rights reserved.

\section{Introduction}

The digital revolution is not only a technological revolution, but it is primarily a revolution of powers and values. ${ }^{2}$ In the last decade, it has become clear that the services facilitated by digital platforms (e.g., Facebook, Airbnb, Google, Uber) were not as value-neutral, unbiased, and impartial as they originally claimed. ${ }^{3}$ Rather, digital platforms are now well-known for being self-serving, opaque, and imbued with values that determine the types of services offered, shape the interactions between users and service providers, and define who has

\footnotetext{
* Corresponding author: Sofia, Ranchordás, Faculty of Law, University of Groningen, The Netherlands. E-mail addresses: s.h.ranchordas@rug.nl (S. Ranchordás), catalina.goanta@maastrichtuniversity.nl (C. Goanta).

${ }^{1}$ We would like to thank the anonymous reviewers for their insightful comments as well as Luca Belli, Nicolo Zingales, and Luã Fergus Oliveira da Cruz.

2 Benoît Thieulin, 'Gouverner à l'heure de la revolution des pouvoirs' (2018) 164 Pouvoirs 19.

${ }^{3}$ Lucas Introna and Helen Nissenbaum, 'Shaping the Web: Why the Politics of Search Engines Matters' (2000) 16 The Information Society 169; Frank Pasquale, 'Platform Neutrality: Enhancing Freedom of Expression in Spheres of Private Power' (2016) 17 Theoretical Inquiries in Law 487.
} 
a voice and who does not. ${ }^{4}$ Yet, their central role in promoting innovation and growth, creating new communication opportunities, and removing market entry barriers to small and medium enterprises is indisputable. ${ }^{5}$ Thus far, it has remained nonetheless challenging to establish the precise value created by these platforms, how the values conveyed by these platforms differ from national public values, and whether they are contributing to the emergence of a novel source of values parallel to those of domestic law and policy. ${ }^{6}$

A growing number of scholars from different fields has delved into the phenomenon of "platformisation" which seeks to convey the impact of digital platforms on cultural industries, politics, and the economy. ${ }^{7}$ Legal scholars have contributed to this body of scholarship by explaining in general terms how the growing emergence of platform power and values is threatening fundamental rights, competition rules, and democracy. ${ }^{8}$ This strand of literature has particularly delved into the shortcomings of technology (e.g., opacity, complexity, biased algorithmic decision-making or discrimination). ${ }^{9}$

${ }^{4}$ See for instance, Christopher S. Yoo, 'Free Speech and the Myth of the Internet as an Unintermediated Experience' (2010) 78 George Washington Law Review 697. See also the developments regarding content moderation and intermediary liability at European Union level, Opinion of Advocate General Szpunar, Case C-18/18, Glawischnig-Piesczek v Facebook Ireland Limited, ECLI:EU:C:2019:45; Daphne Keller, 'Dolphins in the Net: Internet Content Filters and the Advocate General's GlawischnigPiesczek v. Facebook Ireland Opinion' (Stanford Center for Internet and Society, 4 September 2019) <https://cyberlaw.stanford.edu/ files/Dolphins-in-the-Net-AG-Analysis.pdf $>$.

${ }^{5}$ Communication from the European Commission to the European Parliament, the Council, the European Economic and Social Committee and the Committee of the Regions: Tackling Illegal Content Online. Towards an Enhanced Responsibility for Online Platforms. COM (2017) 555 final.

${ }^{6}$ Luca Belli, Pedro Francisco and Nicolo Zingales, 'Law of the Land or Law of the Platform? Beware of the Privatisation of Regulation and Police' in Luca Belli and Nicolo Zingales (eds), Platform Regulations. How Platforms Are Regulated and How They Regulate Us (FGV, 2017) 59; Eyal Benvenisti, 'Upholding Democracy Amid the Challenges of New Technology: What Role for the Law of Global Governance?'(2018) 29 European Journal of International Law 9; On platform values, see José van Dijck, Thomas Poell and Martijn de Waal, The Platform Society: Public Values in a Connective World (Oxford University Press 2018).

${ }^{7}$ See e.g., Vera Demary, The Platformisation of Digital Markets, IW Policy Paper 39/2015, available at https: //www.iwkoeln.de/fileadmin/publikationen/2015/257401/

Digital_Markets_policy_paper_IW_Koeln.pdf; David B. Nieborg and Thomas Poell, 'The Platformisation of Cultural Production: Theorizing the Contingent Cultural Commodity'(2018) 20 (11) New Media \& Society 4275; David B. Nieborg and Anne Helmond, 'The Political Message of Facebook's Platformisation in the Mobile Ecosystem: Facebook Messengers as a Platform Instance'(2019) 41 (2) Media, Culture \& Society 196; José van Dijck, Thomas Poell and Martijn de Waal, De Platformsamenleving (Amsterdam University Press 2016) 17.

${ }^{8}$ See for instance Orla Lynskey, 'Regulation by Platforms: The Impact on Fundamental Rights' in Luca Belli and Nicolo Zingales (eds), Platform Regulations. How Platforms Are Regulated and How They Regulate Us (FGV 2017).

${ }^{9}$ See for instance Frank Pasquale, The Black Box Society: How Secret Algorithms Control Money, Information (Cambridge, MA: Harvard University Press, 2016); Nicolas P. Suzor, Law-
However, scholars may sometimes overlook that the impact of digital platforms is also experienced in the physical world at the most basic and local levels. Citizens see their neighbourhoods depleted of affordable houses due to the rise of Airbnb or alike tourist accommodation, are surrounded by escooters and are often affected by the accidents, urban nuisance and vandalism that has accompanied their proliferation. ${ }^{10}$ At the same time, citizens also experience the prevalence of digital platforms at other levels as the number of digital municipal services provided by sophisticated platforms grows, or they realize that the tech companies contracted by their cities collect data on every single step they take. ${ }^{11}$ The recent destruction of multiple smart lightposts in Hong Kong in August 2019 as part of the demonstrations against the local government, show the citizens' growing rejection of this loss of privacy. ${ }^{12}$ In spite of these developments, the impact of platform power and values at local level has nonetheless remained overlooked. ${ }^{13}$ The reliance on digital technology provided by Big Tech companies (e.g., Google/Alphabet) is not only putting the protection of human rights at stake, but it is also changing the fulfilment of the mandate of public functions, particularly because of the lack of scrutiny. ${ }^{14}$ Therefore, it is

less: The Secret Rules that Govern our Digital Lives (Cambridge: Cambridge University Press, 2019). See also Rathenau Institute, Digitaliseren vanuit publieke waarden (Rathenau Institute, 6 March 2019) <https://www.rathenau.nl/nl/digitale-samenleving/ digitaliseren-vanuit-publieke-waarden>; Tarleton Gillespie, The Relevance of Algorithms, in Tarleton Gillespie, Pablo J Boczkowski, Kriste A Foot (eds) Media Technologies: Essays on communication, materiality and society (MIT Press 2014) 167-194.

${ }^{10}$ James A. Allen, 'Disrupting Affordable Housing: Regulating Airbnb and Other Short-Term Rental Hosting in New York City'(2017) 26 Journal of Affordable Housing and Community Development Law 151; Dayne Lee, 'How Airbnb Short-Term Rentals Exacerbate Los Angeles's Affordable Housing Crisis: Analysis and Policy Recommendation'(2016) 10 Harvard Law \& Policy Review 229.

11 Privacy International, 'Smart cities: Utopian vision, Dystopian reality' (Amnesty International, 2017) < https://privacyinternational. org/report/638/smart-cities-utopian-vision-dystopian-reality>; Liesbeth van Zoonen, 'Privacy Concerns in Smart Cities' (2016) 33(3) Government Information Quarterly 472; Lilian Edwards, 'Privacy, Security and Data Protection in Smart Cities: A Critical EU Perspective' (2016) 3 European Data Protection Law Review 28.

12 See for instance Ellen Ioanes, 'Hong Kong protesters destroyed "smart" lampposts because they fear China is spying on them' (Business Insider, 26 August 2019) $<$ https://www.businessinsider.nl/hong-kong-protesters-smartlampposts-are-spying-on-them-2019-8?international=true\& $r=$ US>. See also Raj Gaire, Ratan K Ghosh, Jongkil Kim, Alexander Krumpholz, Rajiv Ranjan, R K Shyamasundar et al., 'Crowdsensing and Privacy in Smart City Applications' in Danda B Rawat and Kayhan Zrar Ghafoor (eds) Smart Cities Cybersecurity and Privacy (Elsevier 2019) 57; Kati Brock, Elke den Ouden, Kees van der Klauw, Ksenia Podoynitsyna and Fred Langerak, 'Light the way for smart cities: Lessons from Philips Lighting' (2019) 142 Technological Forecasting and Social Change 194; Daniel van den Buuse and Ans Kolk, 'An exploration of smart city approaches by international ICT firms' (2019) 142 Technological Forecasting and Social Change Volume 220

${ }^{13}$ For reflections on platform power exercised globally, see for instance Orly Lobel, 'The Law of the Platform' (2016) 101 Minnesota Law Review 87.

${ }^{14}$ Rikke Frank Jørgensen, 'What Platforms Mean When They Talk about Human Rights' (2017) 9 Policy and Internet 280; Lorna 
important to understand the underlying governance choices made by public authorities and the values they decide to imbue them with. ${ }^{15}$ This article addresses this gap by inquiring into the role and practices of digital platforms in urban centers in the contexts of smart cities and the sharing economy. ${ }^{16}$ Both phenomena are inserted in similar recent debates on the digitalisation of urban centers, the promotion of innovation, efficient allocation of urban resources, and sustainability. ${ }^{17}$ Nonetheless, both sharing-economy and smart-city enabling platforms have been accused of not being as citizen-centric, sustainable, and protective of public values as they claim. ${ }^{18}$ In addition, in both fields we find platforms with significant market power developed by Big Tech that have the capacity to impose their own values on public authorities. Small local smart-city and sharing-economy platforms are thus outside the present analysis, as our focus lies within Big Tech.

In the sharing economy and smart cities, platforms mediate the relationship between citizens and government, reshaping it with their private data-driven and profit-oriented values. Platforms do so because they track, collect, process, and predict information regarding cities and citizens and they support decision-making by relying on big data analysis techniques such as machine learning. ${ }^{19}$ While focused on the influence of platforms in the regulation of local values, this article seeks to touch upon a crucial question with public policy implications: What values do platforms convey in a city, and how do they differ from public values?

In answering this question, we explore the potential conflicts between private, profit-oriented platforms whose priorities are defined by shareholders and their online communities, and the heterogeneous interests of local communities,

McGregor, 'Accountability for Governance Choices in Artificial Intelligence: Afterword to Eyal Benvenisti's Foreword'(2019) 29 European Journal of International Law 1079, 1084.

15 Lorna McGregor, 'Accountability for Governance Choices in Artificial Intelligence: Afterword to Eyal Benvenisti's Foreword' (2019) 29 European Journal of International Law 1079.

${ }^{16}$ Paula Gori, Pier Luigi Parcu and Maria Luisa Stasi, 'Smart Cities and Sharing Economy' (EUI, 2015) <https: //cadmus.eui.eu/bitstream/handle/1814/38264/RSCAS_2015_96. pdf? sequence $=1 \&$ is Allowed $=y>$.

17 See Duncan McLaren and Julian Agyeman, Sharing Cities: A Case for Truly Smart and Sustainable Cities (MIT Press 2015); Anthony Townsend, Smart Cities: Big Data, Civic Hackers, and the Quest for a New Utopia (W W Norton 2013).

${ }^{18}$ For a criticism of smart cities, see for instance, Jiska Engelbert, Liesbet van Zoonen and Fadi Hirzalla, 'Excluding citizens from the European smart city: The discourse practices of pursuing and granting smartness' (2019) 142 Technological Forecasting and Social Change 347; Paolo Cardullo and Rob Kitchin, 'Smart Urbanism and Smart Citizenship: The Neoliberal Logic of 'Citizen-Focused' Smart Cities In Europe' (2018) 37 Environment and Planning C: Politics and Space 813. On the sharing economy, see for instance, Andrea Geissinger, Christofer Laurell, Christina Öberg and Christian Sandström, 'How sustainable is the sharing economy? On the sustainability connotations of sharing economy platforms' (2019) 206 Journal of Cleaner Production 419; Koen Frenken and Juliet Schor, 'Putting the sharing economy into perspective' (2017) 23 Environmental Innovation and Societal Transitions 3.

19 For a general overview of machine learning, see for instance Tom Mitchell et al., 'Machine learning' (1990) 4(1) Annual Review of Computer Science 417. citizens (including underrepresented minorities), and public actors. ${ }^{20}$ In this context, we question the limited transparency of platforms and how this undermines the task of determining the underlying platform values. From a methodological perspective, this article draws its analysis on an interdisciplinary literature review (e.g., law, communication sciences, business, public administration, new media studies) on smart cities, platform values and value creation, as well as on the qualitative content analysis of the terms of service of Airbnb and Lime, and the promotional materials used on the websites of Sidewalk Labs and IBM Smarter Cities as examples of sharing economy and smart city platforms. ${ }^{21}$

We argue that despite the value-creation benefits produced by digital platforms, public authorities should be aware of the risks of technocratic discourses and potential conflicts between platform and local values. ${ }^{22}$ It is in this context that we aim to offer a normative framework for this problem through a co-regulatory or negotiated system that seeks to balance platform and public values. ${ }^{23}$

This article's contribution to existing literature is twofold: first, it offers an innovative legal analysis of the broader impact of digital platforms on public values in the urban context (where platforms tend to have a stronger influence); second, it suggests a normative framework for the protection of public values, based on the notion of local public-interest technology as well as on the introduction of an obligation to take into account the broader impact of private services on public infrastructure.

The article is organized as follows. Section 2 briefly describes how digital platforms have evolved from their traditional role as business matchmakers to influential urban intermediaries. It first defines the notion of value, provides an overview of the values of the platforms under analysis on the grounds of their terms of service, and compares them with public values identified on the basis of literature and public policy documents. Section 3 explores the tension between platform and public values within the context of smart cities and sharing-economy services and their impact on local communities. Section 4 reflects upon the role of digital platforms in smart cities and explains how these actors are conveying their values as providers of public services, to contextualize the normative framework we propose for aligning the values promoted by digital platforms and cities. Section 5 concludes.

\footnotetext{
20 Tarleton Gillespie, Custodians of the Internet: Platforms, Content Moderation, and the Hidden Decisions That Shape Social Media (Yale University Press 2018).

${ }^{21}$ Klaus Krippendorff, Qualitative Content Analysis: An Introduction to Its Methodology (Sage 2004) 15; Marnix Snel and Janaína de Moraes, Doing a systematic literature review in legal scholarship (Boom Juridische Uitgevers 2017).

22 See also Sara Hofman et al., 'The Public Sector's Role in the Sharing Economy and the Implications for Public Values' (2019) Government Information Quarterly (forthcoming).

${ }^{23}$ For a very brief analysis of co-regulation in the context of an earlier form of the sharing economy, see Michele Finck and Sofia Ranchordas, 'Sharing and the City' (2016) 49 Vanderbilt Journal of Transnational Law 1299.
} 


\section{Digital platforms and their values}

\subsection{The emergence of the urban platform economy}

In the early 1970s, students from Stanford University's Artificial Intelligence Laboratory concluded the world's first digital peer-to-peer transaction, using ARPANET, the Internet's precursor network, to purchase drugs from fellow students from the Massachusetts Institute of Technology. ${ }^{24}$ Two decades later, the New York Times was writing about the first sale made on the Internet as we know it today, which entailed a transaction consisting in a Sting CD. ${ }^{25}$ With the advent of microcomputing and the rise of Internet penetration in individual households, e-commerce became the first industry that shaped the notion of digital platforms as we currently identify them, by turning the intermediation of consumer transactions into a lucrative business model. As Internet users found more familiarity in the virtual sphere, digital platforms (e.g., Google, Facebook, Twitter, eBay), already regarded as intermediaries, started providing an increasingly wider range of information society services. ${ }^{26}$ The emergence of such intermediaries contributed to the development of online transactions, as these 'matchmakers' hosted information, facilitated the intermediation of transactions between strangers, and matched supply and demand. ${ }^{27}$ About a decade ago, Airbnb, Uber, Lyft, and other 'sharing-economy' platforms (broadly defined) started relying on this technology to offer services that would allow individuals to share their apartments, vehicles or other goods with strangers. ${ }^{28}$ The sharing-economy disrupted at first existing regulated sectors (e.g., hotels, taxis) and was at the outset of significant litigation throughout the world. In the last eight years, the sharing economy, the 'gig economy' or the platform economy have occupied hundreds of legal scholars throughout the world. ${ }^{29}$ As national and local governments

\footnotetext{
${ }^{24}$ John Markoff, What the Dormouse Said: How the Sixties Counterculture Shaped the Personal Computer Industry (Penguin 2006) 20. See also Jamie Bartlett, The Dark Net (Melvile House 2014).

${ }^{25}$ Peter H Lewis, 'Attention Shoppers: Internet Is Open' (New York Times, 21 August 1994) <https:/www.nytimes.com/1994/08/ 12/business/attention-shoppers-internet-is-open.html>.

${ }^{26}$ See for instance, David Evans, 'The Antitrust Economics of TwoSided Markets' (2003) 20(2) Yale Journal on Regulation 327; also more recently, David Evans and Richard Schmalensee, Matchmakers: The New Economics of Multisided Platforms (Harvard Business Review Press 2016).

27 Evans and Schmalensee fn 25.

${ }^{28}$ For early scholarship on the implications of the sharing economy see for instance Charles Gottlieb, 'Residential Short-Term Rentals: Should Local Governments Regulate the Industry' (2013) 65 Planning \& Envtl L 4; Anne-Marie Slaughter, 'Filling Power Vacuums in the New Global Legal Order' (2013) 36 B C Int'l \& Comp L Rev 919.

${ }^{29}$ See for instance Vanessa Katz, 'Regulating the Sharing Economy' (2015) 30 Berkeley Tech LJ 1067; John O McGinnis, 'The Sharing Economy as an Equalizing Economy' (2018) 94 Notre Dame L Rev 329; Erez Aloni, 'Pluralizing the Sharing Economy' (2016) 91 Wash L Rev 1397; Matthew T Bodie, 'Lessons from the Dramatists Guild for the Platform Economy' (2017) 2017 U Chi Legal F 17; Leah Wing, 'Social Impact and Technology: Issues of Access, Inequality and Disputing in the Collaborative Economy' (2014) 1 IJODR 150; Michael Todisco, 'Share and Share Alike: Considering Racial Dis-
}

start bending or revising their legal frameworks to address the challenges of unregulated sharing or 'gig' services, legal literature has shifted its interest to other topics. ${ }^{30}$ However, this shift does not take into account one of the key impacts of the platform economy: sharing-economy platforms are changing the landscape of cities and have a profound influence on local values. ${ }^{31}$

Although it has been clear for almost two decades that digital platforms would change our economy, platforms have thus far been regulated as value-neutral hosts of information. $^{32}$ This traditional view no longer encompasses the current impact of digital platforms on our society, economy, and politics. ${ }^{33}$ Digital platforms have become regulators, vehicles of communication, innovation, online dispute resolution, and value creation. ${ }^{34}$

Big Tech platforms in particular have become the new essential infrastructures for information, economic and political influence. ${ }^{35}$ Although this phenomenon should not come as a surprise, the growing power of private platforms at the local level is nonetheless problematic for three reasons. First, urban centers with the ambition to become smart cities are currently partnering up with Big Tech to contract not only for software, but also to implement interconnected digital sensors and systems that influence the way cities are planned, how citizens move in a city, and the type of services offered. ${ }^{36}$ While, for example, Huawei offers useful digital platforms for cities, it is also well-known that this company has been under investigation in different countries on suspicion of espionage

crimination in the Nascent Room-Sharing Economy' (2014-2015) 67 Stan L Rev Online 121; Irina Domurath, 'Platforms as Contract Partners: Uber and beyond' (2018) 25(5) Maastricht Journal of European and Comparative Law 565; Christoph Busch, 'The Sharing Economy at the CJEU: Does Airbnb Pass the Uber Test' (2018) 7(4) Journal of European Consumer and Market Law 172; Sofia Ranchordas, 'Peers or Professionals: The P2P-Economy and Competition Law' (2017) 1 Eur Competition \& Reg L Rev 320.

${ }^{30}$ See for instance Andrew G Malik, 'Worker Classification and the Gig-Economy' (2017) 69 Rutgers UL Rev 1729, 1745; Michael L Nadler, 'Independent Employees: A New Category of Workers for the Gig Economy' (2018) 19 NC JL \& Tech 443, 445.

${ }^{31}$ See for instance Sarah Kessler, "The "Sharing Economy" Is Dead, And We Killed It' (Fast Company, 14 September 2015) <https://www.fastcompany.com/3050775/ the-sharing-economy-is-dead-and-we-killed-it>.

32 See for instance, Richard Posner, 'Antitrust in the New Economy' (2000) 68 Antitrust L. J. 925.

33 Van Dijck, Van Poell and de Waal fn 8.

${ }^{34}$ For a thorough analysis of the different roles of platforms, see Rory van Loo, 'The Corporation as Courthouse' (2016) 33 Yale J. Reg. 547, 553; Tarleton Gillespie, 'The Politics of 'Platforms' (2010) 12(3) New Media \& Society 347; Tarleton Gillespie, Moderation, and the Hidden Decisions That Shape Social Media (Yale University Press 2018).

${ }^{35} \mathrm{~K}$ Sabeel Rahman, 'Regulating Informational Infrastructure: Internet Platforms as the New Public Utilities' (2018) 22 Georgetown Law Technology Review 234; Tarleton Gillespie, 'Platforms Are Not Intermediaries' (2018) 22 Georgetown Law Technology Review 198.

${ }^{36}$ Francisco Klauser, Till Paasche and Ola Söderström, 'Smart Cities as Corporate Storytelling' (2014) 18(3) City 307; Anthony Townsend, Smart Cities: Big Data, Civic Hackers, and the Quest for a New Utopia (WW Norton \& Company 2014) 64. 
and alleged trade-secret theft. ${ }^{37}$ This extreme example does not necessarily reflect the practices of other Big Tech companies, but it helps us illustrate the risks of a potential misalignment between public and private interests, the existence of hidden interests, and the lack of transparency of digital platforms. It is this lack of transparency that extends to the relationship between public authorities and private platforms not only in the context of public procurement and outsourcing of IT-services but also when it comes to regulated platforms. Another illustration is the relationship between Airbnb and the municipality of Amsterdam. In the early days of homesharing in Amsterdam, the municipality celebrated a confidential memorandum of understanding with Airbnb allowing this platform to operate temporarily "beyond local law." 38 The platform was able to establish itself very quickly to the growing discontent of Amsterdam residents and attract thousands of hosts and guests. These type of arrangements or informal partnerships are also found in the context of smart cities in the mobility sector. Lime, the global leading platform for electric scooters, has recently partnered with the cities of Omaha, Detroit, and Charlotte to reduce traffic congestion. This partnership has also been designed as a pilot to test the efficacy of micro-mobility (e.g., electric scooters) to improve urban mobility. However, as this article later explains, such arrangements are not as unproblematic as they seem.

Second, as a result of the expansion of digital platforms in cities, their values and related global trends (e.g., cosmopolitan tourism) appear to have started to prevail in the context of these contractual or informal 'partnerships' and over national public values, resulting in the decharacterisation of neighbourhoods, exclusion of residents from the city center, and gentrification of traditional urban centers. Third, as cities become imbued with platform values, we observe a new shift in the power dynamics from public authorities to private actors that do not pursue the public interest with a certain measure of democratic legitimacy. The cooperation between public and private actors results thus not only in the privatisation of public services but also in the transformation of public values. ${ }^{39}$ This phenomenon is connected to the more general problem of misalignment of public and private interests. While both public and private entities tend to attend to the interests and needs of their customers, it is well-known they do it in very

${ }^{37}$ Adi Robertson, 'Huawei executive accused of helping steal trade secrets' (The Verge, 22 May 2019) <https://www.theverge.com/2019/5/22/18636237/huaweicnex-trade-secrets-lawsuit-eric-xu-accusation-trial-hearing>. See also Michael Plachta and Bruce Zagaris, 'Sanctions and Int'l Human Rights' (2019) 35 IELR 62, 65.

38 This document is available at https://www. binnenlandsbestuur.nl/Uploads/2016/2/2014-12-airbnb-irelandamsterdam-mou.pdf (last accessed on October 7, 2019). As it was initially unclear whether Airbnb fitted within existing legal qualifications and the platform did not violate directly any national or local rules, it is important to underline that the municipality merely agreed not to enforce existing rules on tourist accommodation as regards Airbnb hosts. This position has changed considerably since 2014. The platform has signed more recent agreements with the municipality to help the latter enforce new rules that restrict the maximal rental period.

${ }^{39}$ For a critical analysis of the privatisation of city services, see Gerald Frug, 'City Services' (1998) 73 N. Y. U. Law Rev. 23, 29-30. different ways. ${ }^{40}$ The boundary between the public sphere and the respective rights and duties of citizens has become thus blurred due to the growing power of digital platforms that not only offer commercial services to consumers but also disrupt once regulated services and digitise local services, reshaping the relationship between public authorities and citizens. ${ }^{41}$

\subsection{Platforms as generators of values}

Thus far, the notion of 'digital platform' has been used to depict BigTech intermediaries, whether within the realm of the 'sharing' or 'gig' economy, or outside it, for example on social media. ${ }^{42}$ The core technology transacted by these companies has been software (e.g., apps, online platforms) developed on the basis and/or for the enabling of big data collection. With the increase of functionalities performed by connected machines on the Internet of Things ('IoT'), we advance the idea that the next generation of digital platforms will be defined by companies that add electrical engineering expertise (e.g. hardware). New digital platforms will not only be present in smartphones and other personal computing devices, but also in machines from the physical public or private space that did not traditionally include a computer and urban furniture, such as lightposts. ${ }^{43}$ This article thus uses a broader definition of 'digital platforms' which also includes platforms that are developed to support different types of sensors.

Before delving into the matter of what values are conveyed by digital platforms, we must acknowledge what we mean by 'value'. 'Value' is a concept that can be interpreted in a plethora of ways, as it has importance for philosophy, economics, sociology, public administration and law, to name a few examples. In this article, we employ it to reflect on moral qualities, as values 'are the principia of practical thought.'44 Given that the morality dimension implies the consideration of what is right and what is wrong, ${ }^{45}$ the notion of 'value' as

\footnotetext{
40 Jean Damascene Twizeyimana and Annika Andersson, 'The public Value of E-Government-A Literature Review' (2019) 36 Government Information Quarterly 167, 168.

${ }^{41}$ Ida Lindgren, Christian O. Madsen, Sara Hofmann and Ulf Melin, 'Close Encounters of the Digital Kind: A Research Agenda for the Digitalisation of Public Services' 1(2019) 36 Government Information Quarterly 427, 432.

${ }^{42}$ Social media is often not included in scholarship on the gig economy, although Youtube, launched in 2005, predates Airbnb and Uber, launched in 2008 and respectively in 2009, and it has a similar business model: connecting a broadcaster to a peer audience. See Catalina Goanta and Sofia Ranchordás, 'The Regulation of Social Media Influencers: An Introduction' in Catalina Goanta and Sofia Ranchordás, The Regulation of Social Media Influencers (Edward Elgar Publishing, 2020, forthcoming).

${ }^{43}$ Some of these platforms are not new. An example is IBM, one of the oldest companies in the history of computing, see James W. Cortada, IBM: The Rise and Fall and Reinvention of a Global Icon (MIT Press 2019). See for instance Bruce Schneier, Click Here to Kill Everybody (WW Norton \& Company 2018).

44 Peter Railton, Facts, Values and Norms: Essays Towards a Morality of Consequence (Cambridge University Press 2003) 43. See also Nicolai Hartmann, Moral Values (Routledge 2017) 2.

45 Salomon Rettig and Benjamin Pasamanick, 'Changes in Moral Values over Three Decades, 1929-1958' (1959) 6 Soc Probs 320, 321. See also Helmut Coing, 'Analysis of Moral Values by Case-Law'
} 
described in the following sections encompasses what digital platforms associate with these two directions.

When discussing values, it is equally essential to understand not only who holds the values, but also to identify the stakeholders in relation to which such values are held. On the basis of this distinction, the values of digital platforms are manifold, and reflect a diverse ecosystem of stakeholders. For instance, the value of providing affordability to a customer may come at the expense of the interests of workers hired by the platform. In another example, public institutions are supposed to be the embodiment of values endorsed by society at large (e.g. welfare), yet have an equally important interest in maintaining healthy markets.

This brings us to another necessary clarification, namely the difference between values and interests. ${ }^{46}$ To illustrate this, in their role as privately-held companies, platforms are guided by one central interest: profit maximisation. ${ }^{47}$ In itself, this may signal values such as responsibility towards shareholders. Yet, there may be other values companies adhere to, or claim they adhere to, which could potentially be - at least in some ways - contrary to their interests. ${ }^{48}$

While many taxonomies already map and classify public values, ${ }^{49}$ there seems to be no consensus regarding what may be considered as a value, whether in the public or the private sector. It could be argued that the public sector may be defined by having to represent the social values held by society at large (e.g., what society perceives as right or wrong), while in the private sector, the immediate interpretation of the concept of

(1987) 65 Washington University Law Quarterly 711; Thomas Lee Hazen, 'The Corporate Persona, Contract (and Market) Failure, and Moral Values' (1990) 69 North Carolina Law Review 273; James Hitchcock, 'Church, State, and Moral Values: The Limits of American Pluralism' (1981) 44 Law \& Contemporary Problems 3.

46 See, e.g., Margaret Jane Radin, 'Government Interests and Takings: Cultural Commitments of Property and the Role of Political Theory' in Stephen E Gottlieb (eds.), Public Values in Constitutional Law (University of Michigan Press 1993) 69.

47 See for instance Ian B Lee, 'Corporate Law, Profit Maximisation, and the Responsible Shareholder' (2005) 10 Stan JL Bus \& Fin 31.

${ }^{48}$ See for instance Shlomit Azgad-Tromer, 'The Virtuous Corporation: On Corporate Social Motivation and Law' (2017) 19 U Pa J Bus L 341; Angus Corbett, 'Corporate Social Responsibility - Do We Have Good Cause to be Sceptical about It' (2008) 17 Griffith L Rev 413; Tan Seng Teck and Chang Jau Ho and Liau Chee How and Nanthakumar Karuppiah and William Chua, 'A Theorisation on the Impact of Responsive Corporate Social Responsibility on the Moral Disposition, Change and Reputation of Business Organisations' (2018) 8J Mgmt \& Sustainability 105.

${ }^{49}$ See for instance Sara Hofmann, Øystein Sæbø, Alessio Maria Braccini and Stefano Za, 'The public sector's roles in the sharing economy and the implications for public values', Government Information Quarterly $1<$ https://www.sciencedirect.com/science/ article/pii/S0740624X18304106\#bb0305>; Mayuree Yotawut, 'Examining progress in research on public value' (2018) 39(1) Kasetsart Journal of Social Sciences 168; Mark H Moore, Recognising Public Value (Harvard University Press 2013); Briggite Unger, Daan van Der Linde, Michael Getzner, Public or Private Goods? Redefining Res Publica (Edward Elgar Publishing 2017) 232; John Benington and Mark H Moore, Public Value: Theory and Practice (Palgrave Macmillan 2011); Hal G Rainey and Barry Bozeman, 'Comparing public and private organisations: Empirical research and the power of the a priori' (2000) 10(2) Journal of Public Administration Research and Theory 447. 'value' reflects the economic values of markets. ${ }^{50}$ Public and private values are nonetheless not strictly divided, as corporations should embrace social values just as much as government embraces economic values. ${ }^{51}$

Extracting values is a research exercise which may entail a wide array of methods, whether qualitative or quantitative. ${ }^{52}$ This article combines a small qualitative content analysis with a literature review to identify, analyze and compare platform values and public values. ${ }^{53}$

\subsection{Platform values}

\subsubsection{The platform economy and its vision}

The platform economy benefited from particular regular leniency in its early days. In the light of the regulatory subsidies they have received in the past decades, ${ }^{54}$ platforms have traditionally governed themselves through self-regulation. ${ }^{55}$ However, given their growing power even as private actors, platforms may even be considered as 'norm-creating actors besides or within the state' in a legal pluralist understanding. ${ }^{56}$ According to this understanding, platforms create their own legal orders, which complement or compete with the sovereignty of the state in making rules. From this perspective, the self-defined standards enacted by digital platforms give expression to private values which may have an economic or social nature, and are in turn aligned to the platform's interests. These interests may be different from those of the public served by the platform, yet their imposition is possible due to disparities in bargaining power.

This section first addresses the nature of the private/selfregulatory instruments drafted by platforms, and subse-

\footnotetext{
50 See for instance Robert T Slee, Private Capital Markets: Valuation, Capitalisation, and Transfer of Private Business Interests (Wiley and Sons 2011); Mariana Mazzucato, The Value of Everything: Making and Taking in the Global Economy (Penguin Books 2018).

${ }^{51}$ Moore, fn 47. See also Phillip Crowson, 'Adding public value: The limits of corporate responsibility' (2009) 34(3) Resources Policy 105.

52 Elena Harman, Tarek Azzam, 'Incorporating public values into evaluative criteria: Using crowdsourcing to identify criteria and standards' (2018) 71 Evaluation and Program Planning 68.

53 See fn 17.

54 For instance, in the light of the Cambridge Analytica incident, showcasing the lack of accountability mechanisms for sharing user data with third parties, Mark Zuckerberg has even called for more government regulation, The Economist, 'Mark Zuckerberg says he wants more regulation for Facebook' (The Economist, 6 April 2019) <https://www.economist.com/business/2019/04/06/ mark-zuckerberg-says-he-wants-more-regulation-for-facebook>. For the regulation of sharing-economy platforms, see for instance, Stephen R. Miller, 'First Principles for Regulating the Sharing Economy' (2016) 53 Harv. J. on Legis. 147; Daniel E. Rauch and David Schleicher, 'Like Uber, But for Local Governmental Policy: The Future of Local Regulation of the "Sharing Economy"' (2015) Geo. Mason L.\& Econ. Research Paper; Lobel, fn 11.

${ }^{55}$ Christoph Busch, 'Self-Regulation and Regulatory Intermediation in the Platform Economy' forthcoming in Marta Cantero Gamito and Hans-Wolfgang Micklitz (eds) The Role of the EU in Transnational Legal Ordering: Standards, Contracts and Codes (Edward Elgar 2019).

56 Vanessa Mak, 'Pluralism in European Private Law' (2018) 20 Cambridge Yearbook of European Legal Studies 202, 219.
} 
quently discusses selected examples of platform values which may be extracted from the terms of service ('ToS') and community guidelines of platforms that have an impact on cities. For this purpose, we have selected four representative platforms: Airbnb and Lime (as sharing economy platforms), and Sidewalk Labs and IBM Smarter Cities (as smart city platforms).

\subsubsection{Voluntary and mandatory values}

Norm creation by platforms takes the form of ToS, policies and community guidelines. It is also in these documents that we may find the vision that a platform would like to convey as well as the values it holds dear and imposes on its users. As their goal is to define transactional behavior, platforms employ mainly contracts as their primary self-regulatory instruments. Typically, sharing economy platforms create a contractual relationship between the platform and the user on the basis of the platform's general terms. Once all relevant conditions are met (e.g., offer and acceptance), the standard terms delineate the rights and obligations of the parties, and in principle-though depending on the jurisdiction-the terms are binding on the parties to this contract. Due to the scale at which it is used, this contract cannot be negotiated, which results in the platform acting as a self-regulator who defines and imposes its own values onto its users. In contrast, smart city platforms negotiate contracts with local authorities, and these contracts shape the private regulatory framework governing the relationship between the transacting parties. In practice, the ability of local public authorities to truly negotiate these terms may also depend on the dimension and economic power of the city in question.

In this section, we distinguish between two types of values conveyed by platforms to the communities they serve through their services. Voluntary values reflect standards which are not required by state-made law, such as economic values arising out of the provision of customer service. Efficiency and effectiveness are in fact vital for businesses to establish a standard of care for the consumer's needs and build their reputation as trustworthy contracting partners. ${ }^{57}$ In the public sector, public bodies also embrace efficiency and effectiveness as public values in order to ensure that public bodies are pursuing the public interest in the best possible way. However, voluntary values may also produce negative externalities. Consumeroriented values may come at the expense of other stakeholder interests: to meet delivery deadlines, Amazon employees are assigned a performance rate considered by many as inhumane. ${ }^{58}$ Moreover, in the absence of clear public legal standards, platforms may not only embrace what is explicitly allowed, but also what is not explicitly prohibited. An example in this respect are arbitration clauses, which are always unfavorable for consumers because they restrict access to justice and impose unnecessarily high costs on resolving disputes

\footnotetext{
57 See for instance J. Rose, J.S. Persson, L.T. Heeager and Z. Irani, 'Managing e-Government: value positions and relationships' (2015) 25(5) Information Systems Journal 531.

58 Josh Dzieza, “'Beat The Machine”: Amazon Warehouse Workers Strike To Protest Inhumane Conditions' (The Verge, 16 July 2019) < https://www.theverge.com/2019/7/16/20696154/ amazon-prime-day-2019-strike-warehouse-workers-inhumaneconditions-the-rate-productivity>.
}

arising out of business-to-consumer ('B2C') transactions. In jurisdictions where they are not prohibited, companies impose them on consumers by virtue of the 'take-it-or-leave-it' nature of the terms of service.

As digital platforms adapt to new regulations, compliance becomes an actively pursued interest which increases the level of protection offered to individuals, and translates into an adoption of public values into the private legal framework. ${ }^{59}$ With the emergence of stringent regulatory frameworks focused on individual protections (e.g., the Unfair Contract Terms Directive, the European General Data Protection Regulation), the bargaining power gap between digital platforms and users is somewhat reduced. ${ }^{60}$ The values promoted by platforms in their compliance efforts may be considered as mandatory values.

A subsequent question in the case of sharing economy platforms arises with respect to the nature of the contract concluded between the digital platform and the user. While the specific qualification may depend on the nature of the industry in which the platform is active, the intermediation provided by the platform is an information service. Under the framework of the European consumer protection applicable to $\mathrm{B} 2 \mathrm{C}$-transactions, a contract regarding an information service is considered a contract for digital content, either 'allowing the creation, processing or storage of data in digital form' or 'allowing sharing of and any other interaction with data in digital form provided by other users of the service'. ${ }^{61}$

What is more difficult to ascertain is the legal nature of policies and community guidelines which tend to be the source of platform values or at least the documents in which they are conveyed to the public. There are three ways in which these instruments can generally be interpreted. First, policies and community guidelines can be considered to be part of the standard terms, and thus binding to the extent allowed by national contract law. Second, they may be qualified as codes of conduct adopted by the platforms, and thus with a more limited binding force. ${ }^{62}$ Third, depending on the nature of the provisions referred to in the various complementary instruments, it could be argued that some clauses may be legally binding (and thus part of the standard terms), while others may not (and consequently be seen as provisions from a code of conduct). This distinction is highly relevant when dealing

\footnotetext{
59 Lya G. Soeteman-Hernandez, Margarita D. Apostolova, Cindy Bekker, Susan Dekkers, Roland C. Grafström, Monique Groenewold, et al. 'Safe innovation approach: Towards an agile system for dealing with innovations' (2019) Materials Today Communications <https://www.sciencedirect.com/science/article/pii/ S2352492818304239>.

60 Council Directive 93/13/EEC of 5 April 1993 on unfair terms in consumer contracts [1993] OJ 1993, L 95; Regulation (EU) 2016/679 of the European Parliament and of the Council of 27 April 2016 on the protection of natural persons with regard to the processing of personal data and on the free movement of such data, and repealing Directive 95/46/EC [2016] OJ 2016, L 119.

${ }^{61}$ Article 2 (b) and (c), Proposal for a Directive on certain aspects concerning contracts for the supply of digital content, COM(2015) 634 final.

62 Anna Beckers, 'Towards a Regulatory Private Law Approach for CSR Self-Regulation? The Effect of Private Law on Corporate CSR Strategies' (2019) 27(2) European Review of Private Law 221-244.
} 
with the enforcement of standards that reflect values. For instance, a value such as accountability may be expressed by a platform in its community guidelines. However, if guidelines are considered not to have any binding force, the value expression does not lead to any rights or remedies that could enforce it in practice. To illustrate these distinctions, the following section delves into the private/self-regulatory instruments employed by Airbnb, Sidewalk Labs and IBM Smarter Cities and further discusses selected provisions.

\subsubsection{Platform values in terms of service and marketing ma- terials}

When users make accounts on Airbnb, they agree to the platform's ToS, a document with almost 25,000 words which will represent the basis of their agreement. The ToS includes clauses referring to the platform's content and reflects the intermediary nature of Airbnb, as it accounts for its relationship with hosts, but also with tenants/guests. The ToS showcase the bargaining power exercised in the transactional triangle (Airbnb - hosts - guests). For instance, Airbnb applies the same standard to both hosts and renters when it comes to content. On the one hand, Airbnb grants users a 'limited, non-exclusive, non-sublicensable, revocable, non-transferable license' to download and access content on the platform, including that of other users. ${ }^{63}$ On the other hand, the content created by members themselves is licensed to Airbnb using a 'non-exclusive, worldwide, royalty-free, irrevocable, perpetual (or for the term of the protection), sub-licensable and transferable license'. ${ }^{64}$ However, when looking at the exclusion of liability clauses, Airbnb imposes exclusions not only with respect to its own obligations, ${ }^{65}$ but also to those of hosts. ${ }^{66}$ The ToS do acknowledge such exclusions may be unlawful in some jurisdictions, and thus specify that they only apply to the maximum extent permitted by law. Just like every other platform under scrutiny, Airbnb also has a privacy policy, and in addition, a copyright policy, and a cookie policy. Many of the clauses included in such policies deal with disclosures, mostly mandated by law (e.g., data retention and erasure ${ }^{67}$ ).

A more recent type of sharing economy service that currently enjoys enormous popularity in smart cities, is that of micromobility. Popular platforms like Lime change the contractual constellation through their business model, by intermediating and providing access to a fleet of company-owned electric scooters deployed on the streets of a given city. ${ }^{68}$ While Uber built its business model on not purchasing cars, but rather relying on the cars of its riders, e-scooter businesses entail the ride-sharing company is the one making the entire infrastructure available to the public. This infrastructure generally consists in the digital platform (website and app), and

\footnotetext{
63 Clause 5.4 Airbnb ToS.

${ }^{64}$ Clause 5.5 Airbnb ToS.

65 Clause 17 Airbnb ToS.

${ }^{66}$ Airbnb Experiences Guest Release and Waiver, <https://www. airbnb.com/terms/experiences_guest_waiver>.

${ }^{67}$ Clause 6.4 Airbnb Privacy Policy <https://www.airbnb.com/ terms/privacy_policy\#sec6>.

68 Cornelius Hardt Klaus Bogenberger, 'Usage of e-Scooters in Urban Environments' (2019) 37 Transportation Research Procedia 155.
}

the e-scooter fleet (including parking locations). As the consumer only interacts with the platform, both for data tracking (e.g., using the platform digital infrastructure for finding the e-scooters on a map), as well as the rental of goods, a B2Ccontract arises. The rental of Lime products (the company also has a fleet of bikes, e-bikes and ridesharing vehicles) is at the core of what it calls the 'User Agreement', an approximately 18,000 word-long set of standard terms that overall emphasize values such as safety, the protection of minors, but also general user obligations when using the e-scooter. In addition, Lime imposes on the user the company's release of any collective claims relating to its products, showing that whatever fairness value may be imbued in the general terms, the company tries to restrict it by limiting the customer's access to justice. Interestingly, the User Agreement extends this release to third parties such as employees, agents or affiliates, but more importantly, it also stipulates this release to the benefit of 'municipalities and public entities (including all of their respective elected and appointed officers, officials, employees and agents) which authorize Lime to operate any of its Services. ${ }^{69}$ In other words, the standard terms consumers need to agree to before using Lime products and services exclude the possibility of bringing collective claims against public administration entities on the basis of this use. ${ }^{70}$

Another point that deserves particular attention is reflected by data collection and transfers. GPS tracking as that found at the core of the Lime application is infamously sensitive, as it can trace an individual's location history, thereby raising serious data protection (but also moral) questions. ${ }^{71}$ Hackers who disassemble Lime GPS modules have revealed that these are devices (micro-computers) that run on Android and have a 4G-SIM card, which entails that e-scooters are connected to the Internet. ${ }^{72}$ In combination with the acknowledgement that 'Lime may disclose aggregate and other data about [the consumer] in accordance with applicable law, including, without limitation, general latitude and longitude data for [consumer] addresses (provided this would not allow any individual's address to be separately identified) ${ }^{\prime},{ }^{73}$ this may raise additional concerns. Sharing allegedly anonymized data with third parties without any further specifications may mislead consumers when using the Lime app. Especially since Lime seems to collaborate with Uber, $^{74}$ and this collaboration entails data sharing between the two companies, transparency ought to be one of the guiding values promoted by Lime, but it is not.

${ }^{69}$ Clause 5.1(iii) Lime User Agreement.

70 This clause, just as the rest of the User Agreement, is valid only to the extent it does not contravene to mandatory rules at the national level. For instance, according to European consumer law, this clause may be judicially deemed unfair according to the Unfair Contract Terms Directive, fn 58.

${ }^{71}$ Associated Press, "'Tracking every place you go": Weather Channel app accused of selling user data' (The Guardian, 5 January 2019) <https://www.theguardian.com/technology/2019/jan/ 04/weather-channel-app-lawsuit-location-data-selling>.

72 Scootertalk, see <https://scootertalk.org/forum/viewtopic. php?t=1370>.

73 Clause 10.1 Lime User Agreement.

${ }^{74}$ Lime mentions this on its website, see <https://www.li.me/ lime-uber-electric-scooter $>$. 
It could be argued that a smart city platform like Sidewalk Labs uses technology to create urban development solutions to problems such as rising rents, traffic congestion, or air pollution. These types of projects require collaboration between the platform local government and local communities. This role places such a service provider in a different type of intermediation, whereby local government, itself unable to generate public-interest technology, outsources this process to tech companies. ${ }^{75}$ As its clients are not peers, but local governments, contractual frameworks will most likely take place under strict rules of national and local administrative law and European public procurement. These contractual terms are thus not made fully available on the company's website which means that our value analysis is complemented here by the literature and the media discussion of specific projects developed by Big Tech platforms. This lack of transparency is also applicable to additional websites made for specific projects belonging to Sidewalk Labs, such as Replica, an urban planning tool. ${ }^{76}$ As an example of the way in which Sidewalk Lab operates, we can shift our attention to the Sidewalk Toronto project, meant to 'shape the city's future and provide a global model for inclusive urban growth'. ${ }^{77}$ Sidewalk published the project Master Innovation and Development Plans (MDIPs) on its website, and while it is not clear whether these are the final plans considered for implementation, this publication can be seen as an attempt to embrace transparency towards project stakeholders. In addition, by taking into account digital accessibility needs and ensuring that such plans can be read by citizens facing various physical barriers, ${ }^{78}$ another value that can be underlined is that of accessibility. As for the content of the MDIPs, Sidewalk Labs lists its own eight commitments of the Proposed Innovation and Funding Partnership, including the deployment of 'cutting-edge technologies to improve urban life', 'spur[ring] economic development', or 'sharing profits associated with certain technologies with the public sector', which generally reflect economic and social values tailored to the needs of a public administration client.

The same approach is taken by IBM Smarter Cities, as it already works with cities such as Busan (Korea), Palermo (Italy), San Isidro (Argentina), San Jose (US), and Yamagata City (Japan) in the context of a pro bono system where IBM would offer consultancy on matters such as public safety, economic development, affordable housing and even social services. ${ }^{79}$ IBM Smarter Cities is the vision and set of technology solutions touting potential contributions to what it calls 'cog-

\footnotetext{
75 David Eaves, Kevin Frazier and Lavanya Singh, 'Public Interest Technology' (Medium, 22 February 2019) <https: //medium.com/digitalhks/entry-i-public-interest-technologya-brief-look-to-the-past-to-identify-pit-in-the-presentbb72cadd593c>.

76 See Replica, <https://replicahq.com>.

77 See Sidewalk Toronto, <https://www.sidewalktoronto.ca/ accessible-midp > .

78 Ibid. Public documents are said to be 'WCAG 2.0 AA compliant and have been validated on PAC3, Adobe Acrobat Pro DC Accessibility Checker'.

79 Smart Cities World, 'Five cities land IBM Smarter Cities Challenge grants' (Smart Cities World, 21 July 2017) <https: //www.smartcitiesworld.net/news/news/five-cities-land-ibmsmarter-cities-challenge-grants-1918>.
}

nitive government' and covering policy areas such as public safety, smart buildings and urban planning. Similarly to Sidewalk Labs, IBM Smarter Cities does not target consumers, and therefore its business model does not need to account for any contractual B2C framework. Out of the areas of interests listed on its website, IBM Smarter Cities safety, social services and affordable housing can be translated into the values of citizen safety, care (welfare), and affordability, and additional values may be inferred - albeit with less clarity - from other areas of interest (e.g., economic development may or may not promote the value of equality). ${ }^{80}$

The examples of digital intermediaries we reflected upon so far in this section account for a wide range of contractual practices employed for the private governance of (mostly B2C) intermediated transactions. Where intermediaries publicize ToS, as was the case for Airbnb and Lime, we can observe a dramatic contrast between the marketing language used to entice consumers, and the overwhelmingly lengthy and carefully worded contractual clauses that primarily aim to limit the platform's liability, and create frameworks that might appear compliant with legal standards. Yet, what are the true values and interests of the platform when drafting such terms? For instance, Lime claims that agreeing to its ToS entails giving Lime 'the right to photograph, videotape, and otherwise record [the consumer's] appearance and voice related to [the consumer's] use of the Services, at any time and from time to time. ${ }^{\prime 81}$ It is unclear what this right aims to achieve. Does it entail that the SIM cards in the GPS module can be used for recordings? The mere consideration that an important contractual clause like this may leave too much space for interpretation should raise concerns regarding the commercial intentions leading to the ToS. Lime may tout its services as 'cleaner and less expensive than a rideshare', or claim that it is 'working with city, university and community partners to enable smart micro-mobility around the world', 82 thereby implying to embrace values such as affordability, collaboration and sustainability. Still, limitation of liability clauses, especially when imposed in legal systems that do not specifically prohibit them, may also show an overarching economic interest that can be said to overpower a value such as fairness. Similarly, Airbnb's marketing speaks about 'unforgettable trips', 'adventures nearby or in faraway places and access unique homes, experiences, and places around the world, ${ }^{, 83}$ which may reflect values related to improving the human experience, such as increasing the livelihood of the global citizen. However, as mentioned above, this sometimes comes at the cost of other stakeholders not targeted by these values, such as locals whose cities become overcrowded by tourism, and who need to bear the negative effects of the imposed platform values. Given the nature of their services and the lack of user agreements, Sidewalk Labs and IBM Smarter Cities list values in their mission statements. ${ }^{84}$ These values are the same as

\footnotetext{
80 Ibid.

81 Clause 12.7 Lime User Agreement.

82 See Lime website, <https://www.limebike.com>.

83 See Airbnb website, <https://www.airbnb.com>.

84 For instance, Sidewalk Labs: standards of sustainability, affordability, mobility, and economic opportunity, see < https://www. sidewalklabs.com/mission/>.
} 
those portrayed by the sharing economy platforms in the discussion above, yet it remains to be seen what kind of values are taken over in the contractual framework with their clients. As contracts capture the intention of the parties with respect to a specific transaction, or even within a broader context than the transaction itself, they are useful in interpreting what this intention actually is. In principle, platforms may have wellarticulated visions about their role in society. However, a closer look at the values these platforms claim to support shows not only that transnational (or 'cosmopolitan') values are applied with disregard for national and local values but also that the implementation of platform values in their business practices may vary considerably.

In the next section, these values will be discussed in comparison with public values driven by public interest, in order to better gauge the potential conflicts emerging out of the public/private divide as applied to the context of smart cities.

\section{Platform values versus public values in the smart city}

\subsection{Defining public values}

The protection of public values is inherently linked to the pursuit of the public interest. Yet, these two concepts are distinct. The 'public interest' represents an ideal that changes with time and place rather than an identifiable content, it refers to the pursuit of the outcomes that best 'serve the long-term survival and well-being of a social collective constituted public. ${ }^{85}$ Public values are those normative judgments that reflect 'a consensus about rights, benefits, and prerogatives to which citizens should and should not be entitled to; the obligations of citizens to society, the state, and one another; and the principles on which government and policies could be based. ${ }^{86}$ Public values are thus broader than rights. For example, accountability, inclusiveness, and efficiency refer to rights that citizens may have (for example, the right to have access to certain documents or the right not to be discriminated) but they also include a moral dimension that goes beyond legal rights. ${ }^{87}$ Drawing on this characterisation, it is clear that any list of national public values is by definition incomplete. In this section, we focus on the public values that are particularly important for cities and we identify a set of public values that are mentioned on a regular basis in national legislation, local policy documents, and scholarship. ${ }^{88}$ To illustrate this point,

\footnotetext{
85 Barry Bozeman, Public Values and Public Interest: Counterbalancing Economic Individualism (George Washington University Press 2007) 12.

86 Ibid. 13-14.

87 Frank Bannister and Regina Connolly, 'ICT, Public Values and Transformative Government: A Framework and Programme for Research' (2014) 31 Government Information Quarterly 119, 120.

${ }^{88}$ See for instance Saskia Sassen, The Global City (Princeton University Press, 2001); Peter J Taylor amd Ben Deruder, World City Network: A Global Urban Analysis (Routledge 2015); Mark Amen et al. (eds), Cities and Global Governance: New Sites for International Relations (Routledge, 2016); Nestor Davidson and Geeta Tewari (eds), Global Perspectives in Urban Law: The Legal Power of Cities (Routledge, 2019).
}

while each English city has its own policies and local values, the Local Government Act of 2000 states that the objective of any local authority should be 'the promotion or improvement of the economic, social and environmental well-being of their area. ${ }^{89}$ This disposition can be interpreted as a reference to a number of public values such as affordability of public services, sustainability, inclusiveness, and promotion of the local economy.

Before delving into an overview of these public values, it is important to distinguish between the creation of public value which aims at the production of value for society and the protection of public values as such. The creation of public value is a broader approach which ensures that a public organisation meets the needs and expectations of citizens. This approach is based on the so-called 'public value management paradigm' which seeks to gain a legitimate mandate from citizens to pursue the public interest by advancing the efficient performance of public authorities, accountability, responsiveness to public needs, and trust. ${ }^{90}$ In order to achieve legitimacy, public authorities need to show that they are transparent, accountable, and open to the input of citizens. ${ }^{91}$ Achieving public value in the context of the digitisation of public services has been regarded as a way to improve efficiency in government, improve public services to citizens, and social values such as inclusion, democracy, transparency, and participation. ${ }^{92}$ Since the liberalisation movement, the conflict between individual and public values has made it more difficult to find a balance between the creation of public value in an economic sense and the protection of public values.

A first set of public values that is often mentioned in scholarship and policy documents pertaining to local public authorities refers to the quality and affordability of public services. ${ }^{93}$ Cities also have a particular interest in safeguarding the public values of availability, stability, and sustainability of certain services of general economic interest such as energy. ${ }^{94}$

Accountability and transparency are often presented as key public values that are being affected in different ways by public authorities' reliance on digital platforms. These two values are for example underlined as key public values of Bristol's social policy and all 'governance arrangements are to be

89 Local Government Act of 2000, Section 4.

90 See Gerry Stoker, 'Public Value Management: A New Narrative for Networked Governance?' (2006) 36 American Public Administration Review 41; Collin Talbot, 'Measuring Public Value-A Competing Values Approach' (The Work Foundation, 2008).

91 This public-value movement towards openness and transparency with reliance on technology was particularly visible during the Obama Administration in the United States and is present in numerous European openness strategies, see Beth Noveck, WikiGovernment: How Technology Can Make Governments Better, Democracy Stronger, and Citizens More Powerful (Brookings 2010).

92 Twizeyimana and Andersson, fn 38.

${ }^{93}$ Hans de Bruijn and Willemijn Dicke, 'Strategies for Safeguarding Public Values in Liberalized Utility Sectors' (2006) 84(3) Public Administration 717.

${ }_{94}$ Marga G Edens and Saskia Lavrijssen, 'Balancing Public Values during the Energy Transition-How Can German and Dutch DSOs safeguard sustainability' (2019) 128 Energy Policy 57; Catherine Butler, Christina Demski, Karen Parkhill, Nick Pidgeon and Alexa Spence, 'Public values for energy futures: Framing, indeterminacy and policy making' (2015) 87 Energy Policy 665. 
agreed, in order to achieve transparency, and ensure accountability to all of our stakeholders, including our customers, contractors, suppliers, our partners and auditors'. ${ }^{95}$

Public values that refer to public services also go beyond their quality and affordability. They also include the neutrality of their provision to citizens, that is, public authorities should be politically neutral and objective in their communication with citizens and provide services to all citizens without imposing certain political views. ${ }^{96}$ Reliance on digital platforms for the provision of public services rarely fulfills this mission. Platforms values which are primarily driven by individualism, tend not to service the primary interests of society, but rather see public administration as a contracting client or as a hurdle that needs to be overcome, in order to have legal access to the market. For example, while Airbnb may contend that the platform aims to support local communities, it not primarily driven by this public value but by their own financial interests. A second aspect where this neutrality may easily disappear refers to the use of digital platforms in the context of smart cities to influence the behavior of citizens in smart cities, for example, through nudging techniques. ${ }^{97}$ When information is filtered, omitted or transmitted in a non-neutral way in order to influence the choices of citizens, the autonomy of citizens may be significantly affected. ${ }^{98}$ Public authorities have the duty to protect information neutrality and diversity.

A second set of public values that we often identify in legislation and policy documents have a social nature. This set includes for example inclusiveness, equality of treatment and access, affordability of (public and private) housing, safety, and the livability of cities. While these values may resonate with most of us nowadays, it is worth underlining that equality of access and treatment when it comes to public services are relatively recent public values. ${ }^{99}$ Digital platforms can on the one hand ensure that more citizens and visitors have access to digital services but on the other they may also exclude less tech-savvy citizens if the services are only available online. ${ }^{100}$ In many cities throughout the world (including Western countries) the digital divide and the limited digital literacy of many

\footnotetext{
95 Bristol City Council, 'Social Value Policy: Creating Social Value in Bristol' (Bristol.gov.uk, January 2019) < https://www.bristol.gov. uk/documents/20182/239382/Social+Value+Policy+-+approved+ March+2016-1.pdf/391b817b-55fc-40c3-8ea2-d3dfb07cc2a0>.

96 Alberto Alemanno and Alessandro Spina, 'Nudging Legally: On the Checks and Balances of Behavioral Regulation' (2014) 12 I $\cdot \mathrm{CON}$ 429.

97 Sofia Ranchordás, 'Nudging citizens through technology in smart cities' (2019) International Review of Law, Computers and Technology (https://www.tandfonline.com/doi/full/10.1080/ 13600869.2019.1590928).

98 Brent D Mittelstadt et al., 'The Ethics of Algorithms: Mapping the Debate' (2016) Big Data \& Society 1, 9.

${ }_{99}$ Bannister and Conolly, fn 85, 124.

100 Beth Simone Noveck, Smart Citizens, Smarter State: The Technologies of Expertise and the Future of Governing (Harvard University Press 2015); Beth C Weitzman, Diana Silver and Caitlyn Brazill, 'Efforts to Improve Public Policy and Programs through Data Practice: Experiences in 15 Distressed American Cities' (2006) Public Administration Review 386, 387. See also Simone Noveck, 'Peer to Patent": Collective Intelligence, Open Review, and Patent Reform' (2006) 20 Harvard Journal of Law \& Technology 123.
}

thousands of citizens is deepening inequality and excluding many residents from city services. ${ }^{101}$

The Toronto Public Service By-law mentions explicitly the need to promote diversity as an integral part of Toronto's civic identity. ${ }^{102}$ Bristol also comprises inclusiveness as one of the key values of the city' social value policy. ${ }^{103}$ As a consequence of the growth of Airbnb and other home-sharing platforms, investment in private houses for tourism has become such an important source of income that residents are leaving cities. While platforms values convey flexibility in housing, this has meant that poor residents living in touristic areas have been terrorized to leave their houses which will later be transformed into Airbnb-houses.

Third, economic growth and the promotion of local economy appear to be also public values highly underlined in local policy documents. For example, the city council of Bristol enhances the importance of promoting 'the local economy, so that micro, small and medium sized enterprises and the voluntary and community sector in Bristol can thrive,' 'creating or promoting local employment, training and inclusive economic sustainability'. ${ }^{104}$

Fourth, Amsterdam as well as other Dutch smart cities have also enhanced the need to advance a new set of public values in recent policy documents, such as privacy, autonomy, and broad democratic participation. ${ }^{105}$ In order to protect these public values in data-driven urban contexts, local public bodies have invested in the development of ethical and data protection impact assessments and hiring their own data scientists and analysts to assess the quality of the data collected in smart cities.

To conclude, traditional cities tend to emerge as a result of a complex interaction between different elements: geography, economy, existence of raw materials. ${ }^{106}$ In the digital age, technology is transforming the planning, organisation, and governance of cities by their ability to forecast new events and needs (e.g., criminality, sustainability) and thus better allocate city resources. ${ }^{107}$ However, technology should nonetheless be used to pursue these values and not the other way around.

\footnotetext{
101 See for instance Harlan Yu and David G Robinson, 'The New Ambiguity of 'Open Government' (2012) 59 UCLA Law Review Discourse 178.

102 Chapter 192 of Toronto's Municipal Code incorporated in 2015 the Toronto Public Service By-law which includes a list of public values that aim to guide public services and the management of resources in this city.

103 Fn 92.

104 Bristol City Council, 'Social Value Policy: Creating Social Value in Policy', available at https://www.bristol.gov.uk/documents/ 20182/239382/Social+Value+Policy+-+approved+March+2016-1. pdf/391b817b-55fc-40c3-8ea2-d3dfb07cc2a0 (last accessed on October 7, 2019).

${ }^{105}$ Rathenau Instituut, 'Hoe beschermen gemeenten publieke waarden in de slimme stad?' [How Do Municipalities Protect Public Values in the Smart City?], available at https: //www.rathenau.nl/nl/digitale-samenleving/hoe-beschermengemeenten-publieke-waarden-de-slimme-stad (last accessed on October 7, 2019).

106 See generally Steven B Johnson, Emergence: The Connected Lives of Ants, Brains, Cities, and Software (Scribner, 2001).

107 Terry Farrell, 'City Making: Many Hands, Over Time'(2018) 13 Journal of Planning \& Environmental Law 6.
} 


\subsection{Balancing platform values with city values}

At first sight, digital platforms privilege specific values in the platform economy: convenience and short-time access over long-term engagements, flexibility over stable employment, sharing of information, objects, and experiences over ownership and discretion. ${ }^{108}$ Platforms in the sharing economy also claim that they promote sustainable transactions. Many citizens have come to accept these values and, in most cases, national and local governments have found a way to regulate them without interfering with the essence of these services. To illustrate, in most cities Airbnb hosts are allowed to rent rooms to tourists without obtaining a license as long as they do so only for a short period of time. Airbnb also claims on a regular basis that they provide 'healthy, diverse, inclusive and sustainable' travel and aim to benefit 'all of its stakeholders, including (....) communities'. ${ }^{109}$

Despite this appearance of harmony with local communities and possibly their values, the platform economy is one of the different urban contexts where we observe the expansion of platform values. Legal literature has nonetheless not yet discussed the broader phenomenon underlying the advancement of platform values at local level. This is particularly important as it has become clear that platform values are not always aligned with national or local values established in existing legal frameworks. Local residents may not wish to benefit from the flexibility and cosmopolitan interaction that Airbnb or other platforms seek to promote. Rather, the safety, affordability, and family-friendliness of their neighbourhoods may be the values that they prefer to hold on to and have entrusted their local representatives to protect.

In addition, digital platforms seek to advance more than economic values. As important vehicles of news, advertisement, and political influence, digital platforms also appear to have intrinsic values regarding for example hate speech, voting behavior, sustainability, and the protection of human rights. ${ }^{110}$ These values are implicitly or explicitly listed in large platforms' community guidelines. Platforms advance these values for example through the promotion of messages to their users on online community forums or the publication of codes of conduct (e.g., Airbnb's Non-discrimination policy). Platforms encourage users who detect content contrary to their 'values' to report it and enforce it themselves by sanctioning users with the removal of content or shutting down accounts. The promotion of platform values is nonetheless problematic for several reasons: first, it is unclear what the nature and relevance of these values are. As platforms become essential infrastructures for communication, business, social and political influence, platform values are starting to affect the public sphere and the public interest. However, here a second problematic aspect arises: platform values may differ from national values. In a certain jurisdiction, the legal and social acceptance of renting out (even if only sporadically) apartments to strangers or even the definition of 'hate speech' may be perceived in very different terms from those adopted by a plat-

\footnotetext{
108 Lobel, fn 11.

109 Airbnb, 'About us' <https://press.airbnb.com/about-us/>.

110 Keller, fn 3.
}

form's online community guideline. Despite the alleged good intentions of platforms, the merit of many of their initiatives to reduce discrimination, and their attempt to take into account local customs, the law and values of platforms are not always aligned with the law and values of the land. This tension has become particularly challenging in the last years as platforms started playing a growing role in the provision of public services (e.g., crowd-management), for example, in the context of smart cities. ${ }^{111}$

In smart cities, IBM, Sidewalk Labs (a subsidiary of Alphabet to which Google also pertains) or Huawei collect and process personal and urban data through Internet-of-Things, big data, and algorithms. ${ }^{112}$ In Toronto, Sidewalk Labs is designing a new district to 'tackle the challenges of urban growth' that would collect data from a wide range of sources to facilitate mobility, logistics, and sustainability solutions. ${ }^{113}$ In April 2019, the Canadian Civil Liberties Association sued Waterfront Toronto, the publicly funded entity responsible for the project, and the Canadian government at three levels (federal, provincial, and municipal powers) over this plan. This innovative plan has been shrouded in secrecy and opacity and has been accompanied by raising concerns (for example, the limited protection of the privacy of Toronto residents). ${ }^{114}$ The media has reported that resigning members of the Waterfront Toronto and the civil society are particularly concerned with the protection of Canadian values and the fact that SideWalk Labs is the one defining the values fed into the digital technology employed in the city rather than democratically elected officials. ${ }^{115}$ Toronto is one of many examples analyzed in this article, of a controversial partnership where digital platforms seek to interfere with local values by promoting a technocratic discourse that is susceptible of violating important public values (e.g., privacy and autonomy of citizens) and the limit the participation of less tech-savvy citizens.

In the last decade, a growing number of cities and local authorities have embraced digital technology either to improve the efficiency and sustainability of their services or with the ambition to transform their urban centers into so-called 'smart cities.' 116 Since there is no consensual definition of 'smart city'-and this article does not only focus on smartcity platforms-we will refer to urban centers that rely more generally on digital platforms to improve the quality of living of their citizens and visitors as 'digital cities'. ${ }^{117}$

111 See, for example, Rob Kitchin, 'The Real-time City? Big Data and Smart Urbanism' (2014) 79 GeoJournal 1-14; Rob Kitchin, 'The Promise and Peril of Smart Cities' (2015) 26(2) Computers and Law. 112 For a legal analysis of the privacy implications of the widespread collection of data in cities, see van Zoonen, fn 9.

113 Laura Bliss, 'How Smart Should a City Be? Toronto Is Finding Out' (Citylab, 7 September 2018) < https://www.citylab.com/design/ 2018/09/how-smart-should-a-city-be-toronto-is-finding-out/ $569116 />$.

114 Ibid.

115 Ibid.

${ }^{116}$ For a literature review on the definition of smart city, see for instance, Margarita Angelidou, 'The Role of Smart City Characteristics in the Plans of Fifteen Cities' (2017) 24 Journal of Urban Technology 3; Andrea Caragliu, Chiara del Bo and Peter Nijkamp, 'Smart Cities in Europe' (2011) 18 Journal of Urban Technology 6.

117 The concepts of 'smart city' and 'digital city' are distinct. See Renata Dameri, 'Comparing Smart and Digital City: Initiatives 
In a smart city, citizens and visitors can use different digital platforms to obtain both public and private services (e.g., finding tourist accommodation, identify the fastest route to go from one point to the other). Thanks to platforms, citizens have become more mobile, several services are more convenient, and cities have the potential to become more sustainable. ${ }^{118}$ However, public authorities may only collect this data, contract with private tech companies providing information services, and regulate local services to promote tourism in the strict pursuit of the public interest and safeguard of public values. ${ }^{119}$

\section{Normative approaches to public-private values supporting local public-interest technology}

The rationale behind the existence of public administration is to give an institutional setting to the enactment of public values in society. ${ }^{120}$ As seen in Section 3, these values shape public policy, public morality, and define various groups of individuals and their preferences. Within an increasingly digitised society, public values are at risk from two perspectives. First, Big Tech may replace public values with private values, which may be opaque and undesirable. Second, by enforcing privately-held socio-legal standards, Big Tech may be seen to compete for the sovereignty of law-making. Each of these points will be discussed below, in order to propose new theoretical and practical solutions for the tensions that we have seen to arise between the public and the private spheres.

Throughout this article we have tried to give illustrations of both public values and platform values. At first sight, these two notions seem to clash when platforms present themselves as guardians of public values: fairness and equality as legal standards and public values will not be interpreted in the same way by the private sector. A telling example in this respect are the lengthy exclusion or limitation of liability clauses that companies like Airbnb and Lime unilaterally impose on their customers. If a property on Airbnb or a Lime e-scooter have a hidden defect that causes a loss to their respective landlords or renters, the law deems it fair for the victim to have a means of both a remedy and an action for them to be placed in a position where the loss would not have occurred. ${ }^{121}$ Yet in their ToS, both companies take any precau-

and Strategies in Amsterdam and Genoa. Are They Digital and/or Smart?' in Renata Dameri and Camille Rosenthal-Sabroux (eds) Smart City: How to Create Public and Economic Value with High Technology in Urban Space (Springer 2014).

118 Kitchin, fn 106.

119 See Christopher Bovis, Public-Private Partnerships in the European Union (Routledge, 2014).

120 Hofmann, Sæb $\varnothing$, Braccini and Za, fn 47.

${ }^{121}$ Unfair Contract Terms Directive, Annex, point a shows there is a presumption that a term limiting the legal liability of a seller in the case of a personal injury is unfair: '(a) excluding or limiting the legal liability of a seller or supplier in the event of the death of a consumer or personal injury to the latter resulting from an act or omission of that seller or supplier. Point (b) of the Annex specifies that a standard term excluding or limiting access to justice is equally presumed to be unfair: (b) 'inappropriately excluding or limiting the legal rights of the consumer vis-D-vis the seller or supplier or another party in the event of total or partial non- tion possible not to be held liable for losses that mandatory law may impose on them. Therefore, they try to exclude their potential accountability.

However, in other ways, private and public values may be very similar, if not complementary. ${ }^{122}$ The sharing economy is said to have led to the creation of a market niche that promotes sustainability because of its increasing profitability. ${ }^{123}$ If additional mandatory values are imbued in the private sector through top-down regulation (e.g., fuel-related limitations and restrictions), sustainability may very well become a shared value. Additional private values we identified earlier, such as collaboration or affordability, may be associated with the public values of participation and citizen care (welfare), as citizens are expected to actively contribute to democratic decision-making or standard setting. ${ }^{124}$ Moreover, the dynamics between values and the interests of institutions or companies upholding them have similarities as well. On the one hand, private values try to reconcile customer centricity with the inherent economic interests of a given business. On the other hand, public values are caught in between the promotion of the greater good of society and the political influence exercised on this process.

We thus posit that in order to better understand how the private values of Big Tech platforms and the public values of state institutions interact and affect one another, it is necessary to move from a narrative of opposition to a model of complementarity at a level which goes deeper than existing approaches to co-regulation. Differences in interests do not always generate differences in values, and if digital platforms see municipalities as more than clients, but as co-creators of business opportunities which benefit local communities, this can shape a new model of local public-interest technology, dependent on the values shared by both platforms and local authorities. Any transportation company, not just Lime, will make safety one of its core values, because its profits depend on public trust, which can be broken easily. ${ }^{125}$ Traffic rules and standards adopted by national and municipal authorities

performance or inadequate performance by the seller or supplier of any of the contractual obligations, including the option of offsetting a debt owed to the seller or supplier against any claim which the consumer may have against him'.

122 Unger, van Der Linde and Getzner, fn 47, 230. See also Konstantin Petrichev, Susan Thorp, 'The private value of public pensions', (2008) 42 Insurance: Mathematics and Economics 1138; Bram Klievink, Nitesh Bharosa and Yao-Hua Tan, 'The collaborative realisation of public values and business goals: Governance and infrastructure of public-private information platforms' (2016) 33(1) Government Information Quarterly 67.

${ }^{123}$ Harald Heinrichs, 'Sharing economy: A potential new pathway to sustainability' (2013) 22(4) GAIA-Ecological Perspectives for Science and Society 228; Boyd Cohen and Jan Kietzmann, 'Ride on! Mobility business models for the sharing economy' (2014) 27(3) Organisation \& Environment 279.

${ }^{124}$ See for instance Juho Hamari, Mimmi Sjöklint and Antti Ukkonen, 'The sharing economy: Why people participate in collaborative consumption' (2016) 67(9) Journal of the association for information science and technology 2047.

125 James Tapper, 'Television presenter Emily Hartridge dies in electric scooter crash' (The Guardian, 14 July 2019) <https://www.theguardian.com/uk-news/2019/jul/13/ tv-presenter-emily-hartridge-dies-in-scooter-crash>. 
equally reflect safety as a value, as do sanctions meant to enforce them. By following a narrative that divides values into public versus private, there is no room left for reflecting on how the private sector can strengthen the public sector and vice-versa. Indeed, there are many risks that need to be carefully considered when blurring this line, and we critically explored some of them in Section 3. As we have explained above, one of the arguments against digitalizing public infrastructure through private services has been that platforms may reshape public values in smart cities and advance a technocratic discourse that may exclude a number of underrepresented groups and less tech-savvy citizens. Yet, exclusion is not only a problem associated with the Big Tech platforms of the 21st century, given that exclusion arising out of technology adoption often reveals more traditional causes, such as 'inequality and social exclusion in the e-society are partly rooted in the capability to access and use information rather than just in the access to technological resources'.126

This brings us to the second point of this normative section. As functional sovereigns, digital platforms not only generate the private economic and legal standards that define their interaction with the users and thus society at large, but they are also the administrators of these standards. In the Airbnb example mentioned earlier in this paper, the need behind an agreement between Airnbn and the municipality of Amsterdam arose out of the convergence of two general interests. On the one hand, Big Tech companies want to retain as much independence as possible in setting their own limits to products and services. On the other hand, municipalities simply do not have the capacity to enforce all their rules in the platform age as this would involve in some cases daily doorto-door inspections to verify who is renting their house legally and who is not. ${ }^{127}$ If municipal regulations limit the number of days for which a home may be rented out, or imposes licensing requirements, the consistent and fair enforcement of such standards is impossible, because the resources necessary for digital monitoring and e-enforcement are at the moment too high. Moreover, local government may not have access to platform data, which renders monitoring attempts somewhat powerless. In consequence, local government needs to collaborate with digital platforms just as much as digital platforms need the support of local government. As Cohen and Sundararajan put it, 'digital platforms [should be utilized] as partners in the regulation of exchange, rather than [...] as adversaries or entities that require governmental regulation. ${ }^{128}$

\footnotetext{
${ }^{126}$ Mike Cushman and Rachel McLean, 'Exclusion, inclusion and changing the face of information systems research' (2008) 21(3) Information Technology \& People 213.

${ }^{127}$ See for instance the legal struggles of the municipality of Amsterdam in its e-enforcement strategies, in a case where user information was scraped by the municipality from Airbnb. District Court of Amsterdam, judgment of 27 June 2018, ECLI:NL:RBAMS:2018:4442.

${ }_{128}$ Molly Cohen and Arun Sundararajan, 'Self-Regulation and Innovation in the Peer-to-Peer Sharing Economy' (2015-2016) 82 U Chi L Rev Dialogue 132. See also Antonio Cordella and Leslie Willcocks, 'Government policy, public value and IT outsourcing: The strategic case of ASPIRE' (2012) 21(4) The Journal of Strategic Information Systems 295.
}

The approach we propose consists in the creation of a legal framework to facilitate this collaboration. Numerous technology companies aim to disrupt the market with aggressive business models which take advantage of legal uncertainty. ${ }^{129}$ This is in some cases possible because laws that were made to fit other decades need time to be adapted by the judiciary or by law-makers, and disruptive innovation thrives - at least temporarily - in this uncertainty. ${ }^{130}$ Evidently, legal uncertainty cannot be fully removed, but it can be improved. One such improvement we propose is the creation of a legal framework at municipal level for technology companies launching new products and services that have a direct impact on public infrastructure (and thus on public values). This legal framework can, instead of regulating specific technologies, focus on a legal duty to negotiate the conditions of the economic activity with the municipality in good faith. In the case of SideWalk Labs and IBM Smart Cities, this is already happening. As the public sector takes on the role of customer, success stories have already developed, such as the case of governmentdriven sharing economy services in Seoul. ${ }^{131}$ This does not mean, however, that success comes without criticism. According to Hofmann et al., in the sharing economy setting, the public sector is dependent on the functionality of the provider, and this dependency 'can endanger the robustness of the public sector'. ${ }^{132}$ However, these arguments can be made for any functionality that is outsourced by local government through tendering procedures (which may very well apply to digital services), including services as trivial as catering for the employees of a given municipality. On a positive note, outsourcing infrastructural needs (e.g.. micromobility, urban planning) for data-driven solution has a wealth of benefits. Firstly, cities would be able to have access to state-of-the-art services they do not have the resources to design internally, and could thus better serve communities. As an example, bike-sharing schemes can be a saving service for large cities that struggle with air pollution and traffic congestion: in 2018, Romanian company Pegas launched its bike-sharing system consisting in the deployment of over 2000 bikes in predefined parking spaces, with the goal of improving the livelihood of locals and tourists alike, while promoting sustainable urban mobility, ${ }^{133}$ which the municipality of Bucharest tried to achieve on earlier occasions with limited success. Secondly, digital platforms can generate new business models in the form of publicinterest technology provided to public authorities instead of to consumers or other businesses. Public-interest technology is an umbrella term for a plethora of options bringing together technologists and public administration, and its burgeoning significance for the convergence of public and private

\footnotetext{
${ }^{129}$ Lobel fn 11, 92.

${ }^{130}$ Hannah A Posen, 'Ridesharing in the sharing economy: Should Regulators impose Über regulations on Uber?' (2015) 101(1) Iowa Law Review 405.

${ }^{131}$ M Jae Moon, 'Government-driven sharing economy: lessons from the sharing city initiative of the Seoul metropolitan government' (2017) 33(2) Journal of Developing Societies 223.

${ }^{132}$ Hofmann, Sæb $\varnothing$, Braccini and Za, fn 47.

133 Irina Marica, 'Local producer ready to launch smart bike sharing system in Bucharest' (Romania Insider, 10 May 2018) <https://www.romania-insider.com/ pegas-smart-bike-sharing-system-bucharest>.
} 
interests raises a multiplicity of additional questions for legal and interdisciplinary research. ${ }^{134}$ Lastly, public-private partnerships where the different parties have the real ability to discuss terms and their underlying values can help promote mandatory values more consistently in order to protect the public values that may be at stake with the rise of data-driven innovation. ${ }^{135}$

\section{Conclusion}

Nowadays, most digital services are built around platforms, which we understand to be a digital system that reduces transaction costs by organizing decentralized information, matching supply and demand, and allowing for different forms of collaboration. ${ }^{136}$ This broad definition of platforms that we have used in this article primarily encompasses the emergence of the digital platform business model which has disrupted the economy (e.g., Airbnb disrupted the tourist accommodation sector) and shifted firms' competition models to data-driven systems. ${ }^{137}$ This concept also includes at least two types of platforms that are becoming increasingly visible in cities: digital platforms developed for smart cities and 'sharing-economy' platforms.

New digital platforms can be used for municipal management, public safety and environmental protection, as well as smart transportation, smart government, smart education, and smart agriculture. While the power of platforms has been comprehensively analyzed when it comes to its global impact, the legal literature has so far only superficially touched upon what this power means for the local values represented and implemented by local authorities. Sharing economy and smart city platforms are, to this extent, two telling examples.

After establishing the theoretical framework relating to the notion of value, in this paper we provided an overview of se- lected private values extracted from the ToS and marketing materials of four different platforms: Airbnb, Lime, Sidewalk Labs and IBM Smart Cities. We then scrutinized interdisciplinary academic scholarship as well as an illustrative number of documents compiled by local authorities, to define and exemplify public values, and to critically address the potential conflict between the public and private value divide, with a specific emphasis on the interests of local communities.

We argued that regardless of the value-creation benefits produced by digital platforms, public authorities should be aware of the risks of technocratic discourses and potential conflicts between platform and local values. In this context, we suggested a normative framework focusing on two points: departing from values shared by platforms and authorities, in order to shape a new kind of knowledge-service creation, namely local public-interest technology; and addressing the digital enforcement issue driven by the functional sovereignty role of platforms, by proposing a negotiated contractual system that seeks to balance platform values with public values.

While the example of smart and sharing cities provides a resourceful starting point in the advancement of the publicinterest technology, this concept is still in its infancy and more research is necessary to determine its meaning, scope, and implications for society. The same can be said for the need to elaborate on new models of negotiated regulation and coregulation that can bring together platforms and local authorities on the basis of their shared values and guarantee a closer alignment of platform and public values.

\section{Declaration of Competing Interest}

The authors declare that they have no known competing financial interests or personal relationships that could have appeared to influence the work reported in this paper.

\footnotetext{
${ }^{134}$ For an overview of this concept, see Bruce Schneier, 'PublicInterest Technology Resources' (Public-Interest Tech, 30 September 2019) <https://public-interest-tech.com>.

${ }^{135}$ Lin Li, Philip Hookon Park and Sung-Byung Yang, 'The role of public-private partnership in constructing the smart transportation city: A case of the bike sharing platform' (2018) Asia Pacific Journal of Tourism Research 1.

136 See for instance, Annabelle Gawer (ed), Platforms, Markets and Innovation (Edward Elgar Publishing 2009); Carlo M Rosotto et al., 'Digital Platforms: A Literature Review and Policy Implications for Development' (2018) 19 Competition and Regulation in Network Industries 93.

137 Aneesh Zutshi and Antonio Grilo,'The Emergence of Digital Platforms: A Conceptual Platform Architecture and impact on Industrial Engineering' (2019) 136 Computers \& Industrial Engineering 546. On the competition impact of digital platforms, see also Ariel Ezrachi and Maurice Stucke, Virtual Competition: The Promises and Perils of the Algorithm-Driven Economy (Harvard University Press 2016).
} 